\title{
Modified Saw Dust for the Removal of Lead Cations from Aqueous Media
}

\author{
Ismail Abbas ${ }^{1}$, Jinane K. Chaaban ${ }^{2} \&$ Iyad Karamé ${ }^{3}$ \\ ${ }^{1}$ Chemistry Department, Faculty of Science, Beirut Arab University, Tripoli, Lebanon \\ ${ }^{2}$ Faculty of Sciences, Lebanese University, Beirut, Lebanon \\ ${ }^{3}$ Department of Chemistry, Lebanese University, Beirut, Lebanon \\ Correspondence: Ismail Abbas, Chemistry Department, Faculty of Science, Beirut Arab University, Tripoli \\ 11-5020, Lebanon. Tel: 961-360-1140. E-mail: i.abbas@bau.edu.lb
}

Received: June 8, 2012 Accepted: June 16, 2012 Online Published: September 20, 2012

doi:10.5539/ijc.v4n5p35 URL: http://dx.doi.org/10.5539/ijc.v4n5p35

\begin{abstract}
Saw dust modified with chloroethylacetate was prepared. The product was used as an extracting agent for the solid-phase extraction of lead cations from aqueous media. The uptake performance of modified saw dust (MSD) for removal of $\mathrm{Pb}(\mathrm{II})$ cations was investigated using batch method. The influences of some experimental parameters like initial concentration of the cation, extraction time, concentration of the saw dust, $\mathrm{pH}$ and temperature were studied. Three adsorption isotherms [Langmuir, Freundlich and Dubinin-Redushkevish (D-R)] were used to analyze the equilibrium data. The sorption capacity of modified saw dust was found to be $78.1 \mathrm{mg} / \mathrm{g}$ at $298 \mathrm{~K}$ from $164 \mathrm{mg} / \mathrm{l}$ aqueous solution of lead cation. The mean free energy calculated from D-R model was found to be $15.81 \mathrm{KJ} / \mathrm{mol}$, indicating that chemisorption is involved in the extraction process. The removal of lead cation does not change with increasing temperature. The present method has been compared with the previous methods.
\end{abstract}

Keywords: modified sawdust, Lead Cation, extraction, adsorption isotherm

\section{Introduction}

Rapid industrialization and poor effluent treatment processes in many industries have led to a substantial lowering of water quality that is fed to water bodies. Presence of heavy metals is one of the many factors that lower water quality. The heavy metals cause adverse effects on health, increase environmental toxicity and affect the aesthetic quality of the water (Parab, Joshi, Shenoy, Lali, Sarma, \& Sudersanan, 2008). The removal of heavy metal in an effective manner from water and wastewater is, thus, ecologically very important. Common cleaning methods for the removal of heavy metal comprise membrane separation (Chakravarti, Chwodhury, Chakraborty, Chakraborty, \& Mukherjee, 1995 ), electrochemical precipitation (Kongsricharoern \& Polprasert, 1996), emulsion per traction (Ortiz, Roman, Corvalan, \& Eliceche, 2003), ion exchange (Trgo, Peric, \& Medvidovic, 2006), preconcentration (Hirata, Honda, \& Kumamru, 1989), fertilization (Mandaoker, Dharmadhikari, \& Dara, 1994) and adsorption (Danil de Namor \& Abbas, 2010 ; Bhattacharya, Naiya, Mandal, \& Das, 2008). These methods differ with respect to cost, complexity and efficiency.

Lead(II) is a well known highly toxic metal considered as a priority pollutant. It directly enters the water bodies through the effluent discharges including battery, paper and pulp, mining, electroplating, lead smelting and metallurgical finishing industries and caused a marked increase in concentrations. In most countries, lead(II) level of water is limited with the value of $0.05 \mathrm{mg} / \mathrm{l}$. It causes various types of acute and chronic disorders. The safe and effective disposal of $\mathrm{Pb}(\mathrm{II})$ containing waste water is a challenging objective for industries because cost effective treatment alternatives are not readily available. A number of adsorbents such as activated carbon (Reed, Arunachalam, \& Tomes, 1994), sargassum (K. Park, M. Park, Jang, E. Kim, \& Y. Kim, 1999), chitosan (Inoue, Ohto, Yoshizuka, Yamaguchi, \& Tanaka, 1997), metal oxide gel (Shubha, Raji, \& Anirudhan, 2001), saw dust (Raji, Shubha, \& Anirudhan, 1997), humus-boehmite complex (Abraham \& Anirudhan, 2001), animal bone powder and ceramics (Abdel-Halim, Shehta, \& El-Shahat, 2003) have been used for lead(II) removal. The idea of using various agricultural products and by-products for the removal of heavy metal from solution has been investigated by number of authors (Low, Lee, \& Liew, 2000). Natural materials that are available in large 
quantities or certain waste from agricultural operations may have potential to be used as low cost adsorbents, as they represent unused resources, widely available and are environmentally friendly.

In the present study, a new adsorbent material prepared from Sweden saw dust has been employed for the removal of lead(II) from wastewater. The main objective of this study is to assess the potentiality of saw dust removal of $\mathrm{Pb}$ (II) from aqueous solutions with a series of batch adsorption experiments. The effects of adsorbent concentration, $\mathrm{pH}$, contact time and initial metal ion concentration on the adsorption capacity were investigated. Adsorption isotherm models and thermodynamic parameters were also investigated to know the adsorption characteristics.

\section{Experimental Section}

\subsection{Chemicals}

Chloroethylether (98\%), acetonitrile, ethanol, methanol and acetone (HPLC grade) were all purchased from Aldrich and used as received. Hydrochloric acid, sodium fluoride, potassium bromide, sodium chloride, sodium hydroxide and calcium chloride were purchased from Fisher Scientific, UK.

\subsection{Preparation of Modified Sawdust}

The Sweden saw dust (SD) was collected, dried and sieved and an average particle size of $1 \mathrm{~mm}$ was considered for the extraction studies. The dried saw dust $(5 \mathrm{~g})$ was mixed with $2 \mathrm{ml}(18.23 \mathrm{mmole})$ of chloroethylether, $7.562 \mathrm{~g}$ (54.7 mmole) of $\mathrm{K}_{2} \mathrm{CO}_{3}$ and $0.2 \mathrm{~g}$ of 18 -Crown-6 (Scheme 1). The mixture was refluxed for 8 hours in $50 \mathrm{ml}$ acetonitrile as a solvent. Then the mixture was filtered using suction filtration, washed with $4 \% \mathrm{NaHCO}_{3}$, distilled water and methanol. Material was then dried under vacuum at $120^{\circ} \mathrm{C}$ for 24 hours before being used.
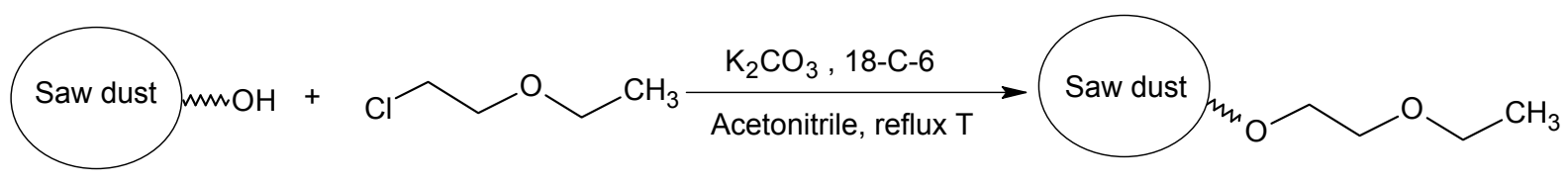

Scheme 1 Preparation of modified saw dust

Modified sawdust

\subsection{Preparation and Determination of Lead Cations Solutions}

The $0.1 \mathrm{M}$ stock solutions of lead were prepared by dissolving accurate amounts of $\mathrm{Pb}\left(\mathrm{NO}_{3}\right)_{2}$ in distilled water $(500 \mathrm{ml})$. Perkin-Elmer Model AAnalyst 400 Atomic Absorption Flame Spectrometer (AAS) was used to determine the concentrations of metal ions in the aqueous phase. Standard solution of lead ions salts were used to calibrate the Spectrometer.

\subsection{Influence of Mass of Modified Saw Dust}

Modified saw dust (0.005-0.04 g) were added to $10 \mathrm{ml}(164 \mathrm{mg} / \mathrm{l})$ lead cation solutions in a set of eight test tubes. The tubes were then shaken on a rotamixer for $5 \mathrm{~min}$ to ensure homogenous mixing, sealed and then left overnight at $25{ }^{\circ} \mathrm{C}$. After equilibrium was attained, the solutions were filtered through $0.45 \mu \mathrm{m}$ Millipore filters (Type HA) and $\mathrm{Pb}$ (II) ions concentrations were determined.

\subsection{Uptake Capacity of Modified Saw Dust}

Adsorption capacities of solid phase were determined under static conditions by the batch method. Solutions of $\mathrm{Pb}$ (II) ions $(10 \mathrm{ml})$ over the concentration range $81-1768 \mathrm{mg} / \mathrm{l}$ were maintained for $24 \mathrm{hrs}$ at $25^{\circ} \mathrm{C}$ with the modified saw dust $(0.025 \mathrm{~g})$. The metal ions in the filtrate were determined with AAS and the amount of cations removed was calculated from the difference in their initial and final concentrations in the aqueous solutions.

\subsection{Effect of the Solution $\mathrm{pH}$}

The efficiency of the MSD to extract lead cations was investigated in the 1.0-6.0 pH range under static conditions. The concentration of the initial ion salt (164 ppm) was kept constant in aqueous solution whilst the solution $\mathrm{pH}$ was adjusted to the desired values by addition of nitric acid. $\mathrm{pH}$ studies in an alkaine medium was not possible due to formation of $\mathrm{Pb}(\mathrm{OH})_{2}$ precipitate.

\subsection{Optimum Contact Time}

The effect of contact time on the percentage removal of $\mathrm{Pb}(\mathrm{II})$ ions was also investigated by the static technique. In this, $0.025 \mathrm{~g}$ of the modified saw dust was added to $10 \mathrm{ml} \mathrm{of} \mathrm{Pb(II)} \mathrm{ion} \mathrm{solutions} \mathrm{(164} \mathrm{ppm)} \mathrm{and} \mathrm{was} \mathrm{left} \mathrm{for} \mathrm{the}$ 
selected period of time (1- $125 \mathrm{~min})$. The mixture was filtered and the free metal ion was determined as described above.

\subsection{Effect of Temperature}

To investigate the temperature effects on the extraction ability of MSD, a fixed amount of MSD was equilibrated with a volume $(10 \mathrm{ml})$ of the lead ion salt solution $(164 \mathrm{ppm})$ at different temperatures $\left(25,30,35,40\right.$ and $\left.45^{\circ} \mathrm{C}\right)$. The phases were separated and the concentrations of lead ion salts in the aqueous phase were determined.

\section{Results and Discussion}

\subsection{Characterization of Adsorbent}

Average particle size of MSD was $1 \mathrm{~mm}$. Elemental analysis showed $43.27 \%$ carbon, $5.34 \%$ hydrogen, $0.09 \%$ Nitrogen for modified saw dust and $48.91 \%$ Carbon, $6.30 \%$ Hydrogen, $0.14 \%$ Nitrogen for original Sweden saw dust.

Fourier transform infrared spectroscopy (FTIR) was used to determine the vibration frequency changes in the functional groups in the adsorbent. The spectra of the adsorbents were measured by an FTIR spectrometer (Bruker Tensor 29) within the range of $400-4000 \mathrm{~cm}^{-1}$ wave number. FTIR spectra for all the adsorbents that is, SD and MSD are shown in Figure 1a and $b$. The spectra indicated a number of absorption peaks showing the complex nature of saw dust. The functional group is one of the keys to understand the mechanism of metal binding on saw dust. There are several functional groups present in saw dust. The changes in the functional groups before and after modification with chloroethylether are confirmed by FTIR spectra.

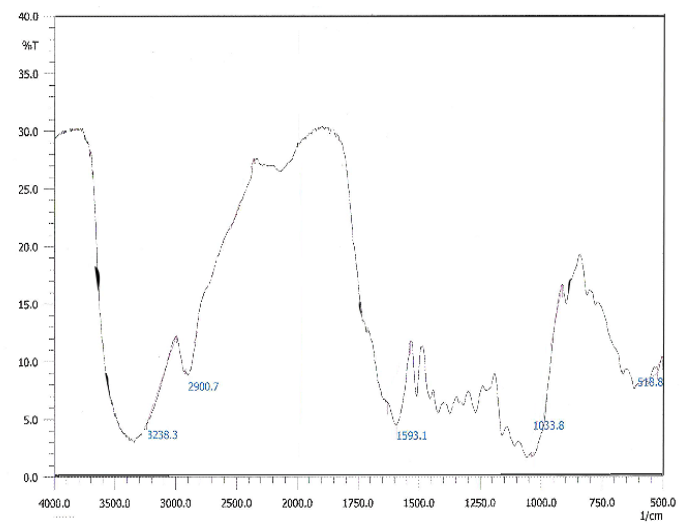

(a)

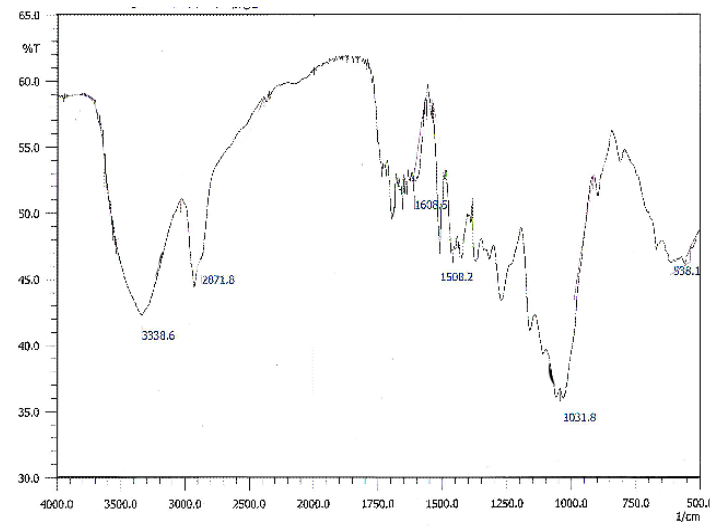

(b)

Figure 1. FTIR spectra of (a) original and (b) modified saw dust

The strong and broad bands from 3200 to $3600 \mathrm{~cm}^{-1}$ correspond to stretching vibration of hydroxyl group and adsorbed water. The bands around $2850-3000 \mathrm{~cm}^{-1}$ were attributed to stretching vibration of $\mathrm{C}-\mathrm{H}$ alkane group. The variable peak at $1638 \mathrm{~cm}^{-1}$ for $\mathrm{SD}$ is attributed to stretching vibration of the $\mathrm{C}=\mathrm{C}$ alkene group. This band was shifted for MSD to $1583.1 \mathrm{~cm}^{-1}$. This indicates a change in chemical structure of the modified sawdust relative to raw sawdust. The strong band observed at $1033.8 \mathrm{~cm}^{-1}$ indicated the stretching of the many $\mathrm{C}-\mathrm{OH}$ and $\mathrm{C}-\mathrm{O}-\mathrm{C}$ bonds (Stuart, 1996). The bands below $1200 \mathrm{~cm}^{-1}$ can be considered as finger print regions.

\subsection{Effect of MSD Dose}

The optimum amount of the sorbent for maximum take up was determined by increasing the amount of modified saw dust $(0.005$ to $0.05 \mathrm{~g})$ added into $10 \mathrm{ml}$ of $164 \mathrm{mg} / \mathrm{L}$ lead ions while keeping other parameters (pH, concentration, and contact time) constant (Figure 2). It can be observed that the uptake capability of the modified saw dust generally improved by increasing its amount in $\mathrm{Pb}(\mathrm{II})$ solution. This is expected due to the fact that the higher amount of material in the solution means greater availability of binding sites for lead ions. 


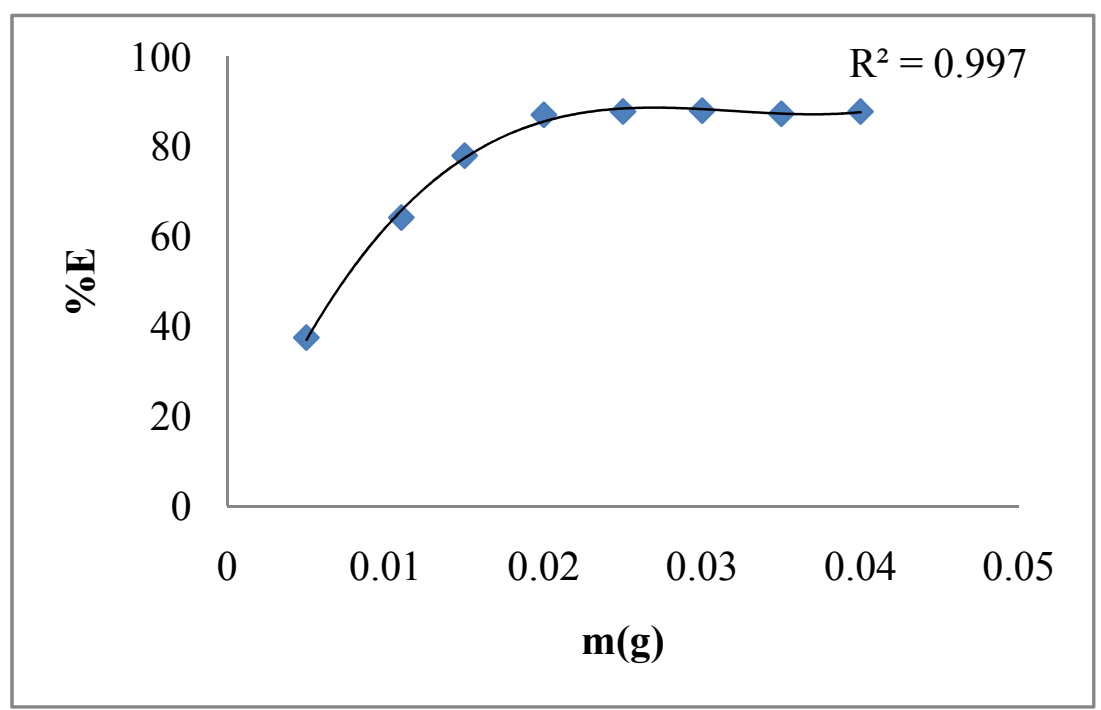

Figure 2. Effect of the amount of MSD on the percentage extraction of lead cations from aqueous media at $25^{\circ} \mathrm{C}$

It was observed that at a given solid/solution ratio $(2 \mathrm{~g} / \mathrm{l})$ no further uptake of $\mathrm{Pb}$ (II) ions from aqueous solution was obtained. This suggests that after a certain amount of solid phase, the maximum uptake is attained and hence the amount of ions bound to the adsorbent and the amount of free ions remains constant even with further addition of the dose of modified saw dust. The maximum percentage of lead cations removed at $2 \mathrm{~g} / \mathrm{l}$ solid/solution ratio was found to be $87 \%$. On the other hand only $20 \%$ of lead ions were removed using the same solid/solution ratio with original SD. This indicates that MSD is more efficient in removing lead cations than un-modified saw dust. This indicates that MSD is more efficient in removing lead cations than un-modified saw dust. It can be also concluded that the ethereal oxygen atoms are acting as major sites in removal of lead cations from aqueous solution.

\subsection{Lead Cation Uptake Isotherms}

In order to estimate the adsorption capacity of the component from liquid phase to solid phase, it is important to perform the equilibrium curves. The equilibrium data were fitted to the well known three adsorption isotherms, namely the Langmuir, Freundlich and Dubinin-Redushkevich (D-R). The Langmuir model assumes monolayer adsorption while the Freundlich model is empirical in nature which assumes the adsorption is heterogeneous on the surface. The Langmuir and Freundlich isotherms do not give any idea about mechanism of extraction. Therefore, Dubinin-Redushkevich isotherm model (Dubinin, \& Radushkevich, 1947) was applied to distinguish between the physical and chemical uptake of lead cation by modified saw dust.

The Langmuir monolayer capacity (Figure 3) of $78.1 \mathrm{mg} / \mathrm{g}(0.377 \mathrm{mmol} / \mathrm{g})$ is quite large. The equilibrium adsorption data (Figures 4-6) of initial lead in the range of $81-1768 \mathrm{mg} / 1$ were fitted to linearly transformed Langmuir Freundlich and Dubinin-Redushkevich equations. The linear equations of Langmuir, Freundlich and Dubinin-Redushkevich are represented as follows (Equations (1), (2) and (3), respectively): 


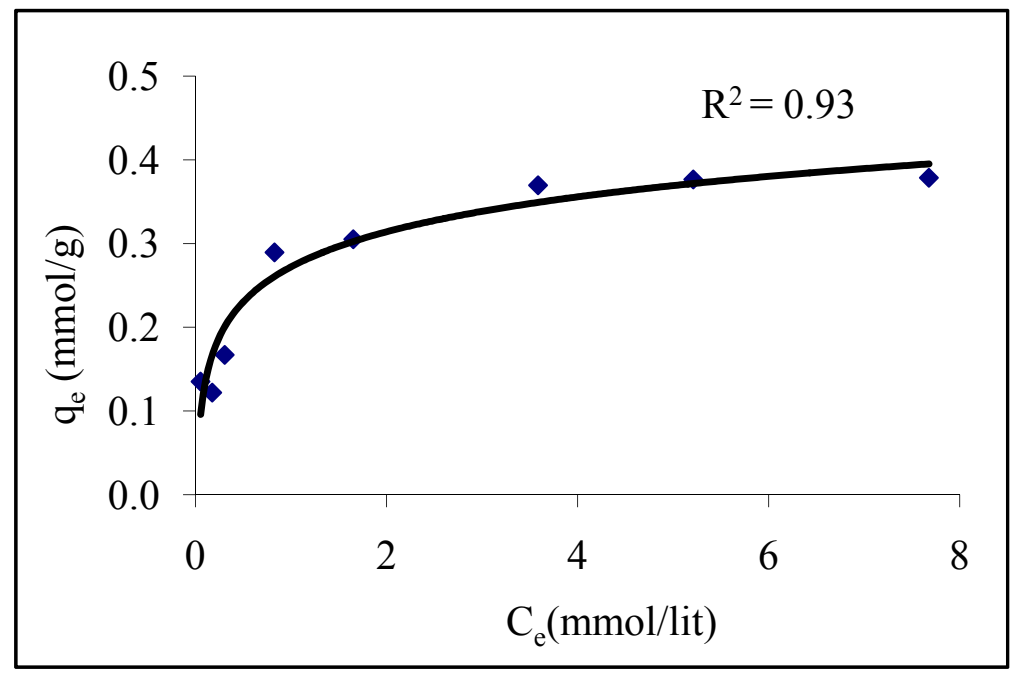

Figure 3. Uptake isotherm for the lead cations from aqueous solution by MSD at $25^{\circ} \mathrm{C}$

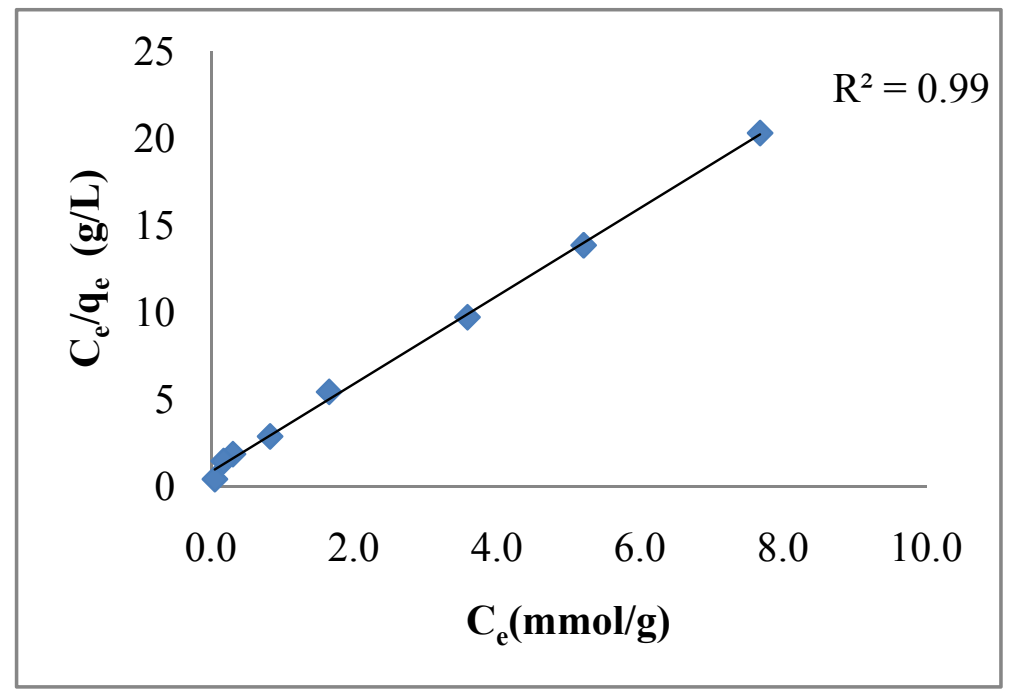

Figure 4. Linearized Langmuir isotherms for $\mathrm{Pb}$ (II) uptake by the MSD at $25^{\circ} \mathrm{C}$

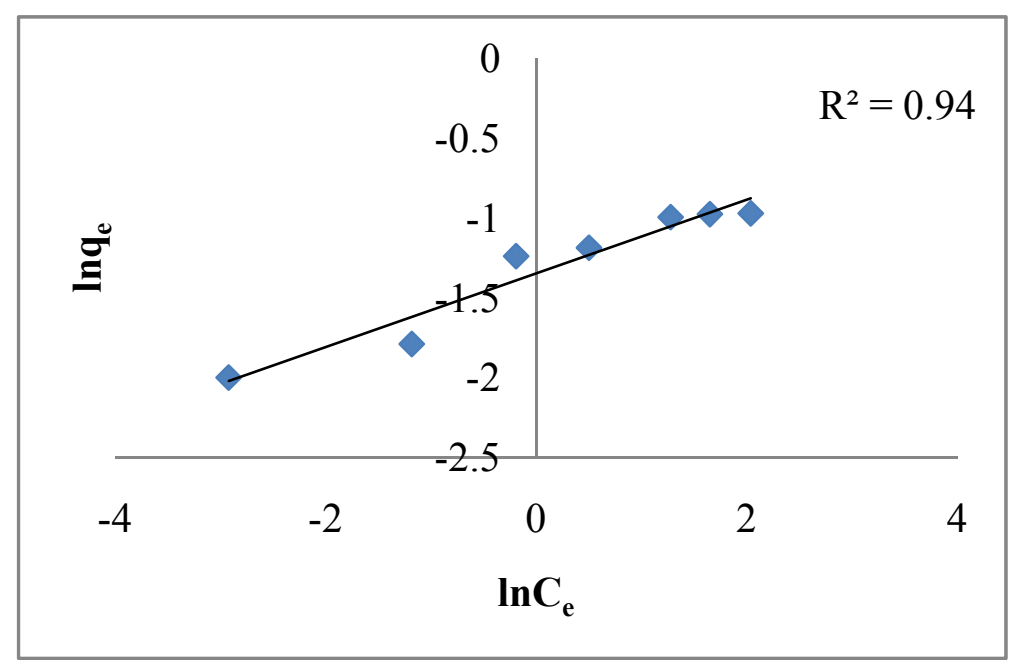

Figure 5. Linearized Freundlish isotherms for $\mathrm{Pb}(\mathrm{II})$ uptake by the MSD at $25^{\circ} \mathrm{C}$ 


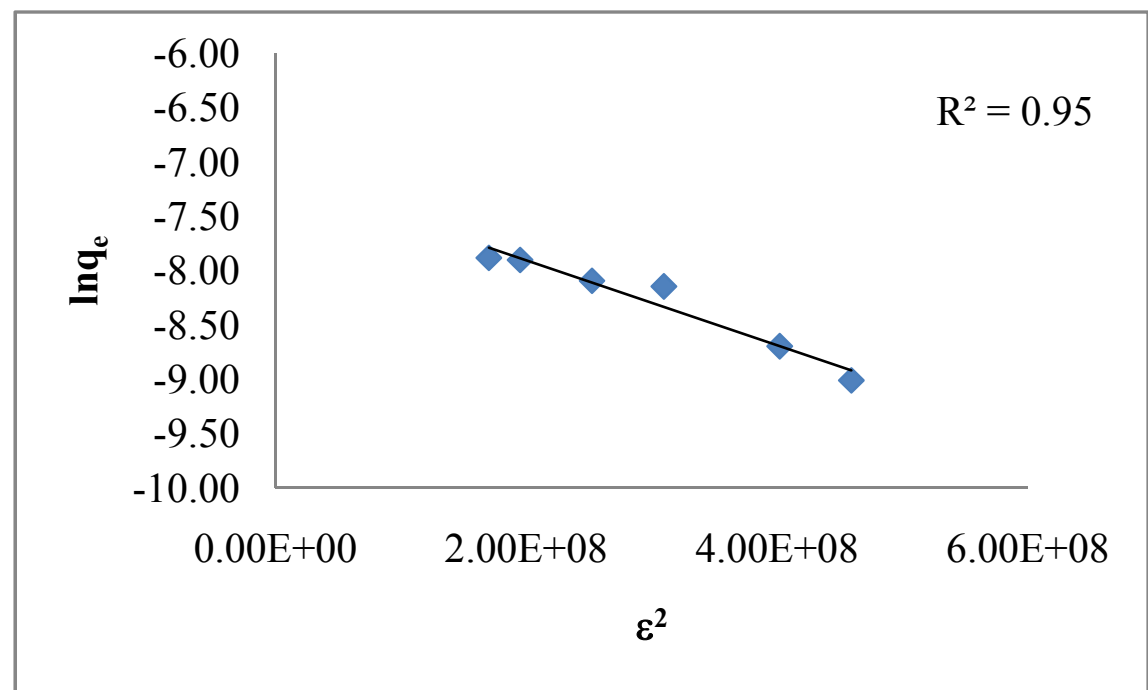

Figure 6. Linearized Dubinin-Redushkevich isotherms for $\mathrm{Pb}(\mathrm{II})$ ion uptake by MSD at $25^{\circ} \mathrm{C}$

$$
\begin{aligned}
\frac{C_{e}}{q_{e}} & =\frac{1}{b q_{m}}+\frac{C_{e}}{q_{m}} \\
\log q_{e} & =\log k+\frac{1}{n} \log C_{e} \\
\ln q_{e} & =\ln q_{m}-\beta \varepsilon^{2}
\end{aligned}
$$

where $C_{e}$ is the equilibrium concentration ( $\left.\mathrm{mmol} / \mathrm{l}\right), q_{e}$ is the amount of cation uptake at equilibrium time $(\mathrm{mmol} / \mathrm{g})$, and $q_{m}$ and $\mathrm{b}$ are Langmuir constants related to the uptake capacity and energy respectively, $k$ and $n$ are Freundlich constants. In eqn. $3, q_{m}$ is the maximum uptake capacity $(\mathrm{mol} / \mathrm{g}), \beta$ is the activity coefficient related to the mean sorption energy $\left(\mathrm{mol}^{2} . \mathrm{J}^{2}\right)$ and $\varepsilon$ is Polanyi potential.

The value of $\varepsilon$ can be calculated from the equation.

$$
\varepsilon=R T \ln \left(1+\frac{1}{C_{e}}\right)
$$

Where $\mathrm{R}$ is the universal gas constant $(\mathrm{J} / \mathrm{mol})$ and $\mathrm{T}$ is the absolute temperature in Kelvin.

The activity coefficient was further used to calculate the adsorption mean free energy $(\mathrm{E} ; \mathrm{KJ} / \mathrm{mol})$ which is the free energy for the transfer of 1 mole of metal ions from the infinity to the surface of the adsorbent, and the relation can be calculated using the Equation 5 .

$$
E=\frac{1}{\sqrt{-2 \beta}}
$$

The constants values of isotherms summarized in Table 1 were obtained from the slope and intercept of the plots of each isotherm. The separation factor $\left(\mathrm{R}_{\mathrm{L}}=0.99\right)$ of Langmuir isotherm model supports the favorable removal of lead cations by the MSD (Danil de Namor \& Abbas, 2010). Generally, the high binding constant $(b=3.087 \mathrm{l} / \mathrm{mmol}$ ) listed in Table 1 supports the uptake of lead cations from the aqueous solution and indicates a high thermodynamic stability of extraction process in aqueous solution.

From Table 1, it is seen that experimental data are better fitted to Langmuir $\left(\mathrm{R}^{2}=0.99\right)$ than Freundlich $\left(\mathrm{R}^{2}=0.93\right)$ adsorption isotherm. The Freundlich isotherm constants $K$ and $n$ are constants incorporating all factors affecting the adsorption process such as of adsorption capacity and intensity of adsorption. The values of uptake coefficients $(0.260 \pm 0.022 \mathrm{mmol} / \mathrm{g})$ and the $1 / \mathrm{n}$ value $(0.23)$ obtained in this study $(0.1<1 / \mathrm{n}<1.0)$ represent beneficial adsorption. 
Table 1. Isotherm constants for the removal of lead cations by MSD at $25^{\circ} \mathrm{C}$

\begin{tabular}{|c|c|c|c|c|c|c|c|c|c|}
\hline \multicolumn{4}{|c|}{ Langmiur } & \multicolumn{3}{|c|}{ Freundlich } & \multicolumn{3}{|c|}{$\mathrm{D}-\mathrm{R}$} \\
\hline $\begin{array}{c}\mathrm{q}_{\mathrm{m}} \\
(\mathrm{mmol} / \mathrm{g})\end{array}$ & $\begin{array}{c}\mathrm{b} \\
(\mathrm{l} / \mathrm{mmol})\end{array}$ & $\mathrm{R}^{2}$ & $\mathrm{R}_{\mathrm{L}}$ & $\begin{array}{c}\mathrm{k} \\
(\mathrm{mmol} / \mathrm{g})\end{array}$ & $\mathrm{n}$ & $\mathrm{R}^{2}$ & $\begin{array}{c}\mathrm{q}_{\mathrm{m}} \\
(\mathrm{mmol} / \mathrm{g})\end{array}$ & $\begin{array}{c}E \\
(\mathrm{KJ} / \mathrm{mol})\end{array}$ & $\mathrm{R}^{2}$ \\
\hline $0.396 \pm 0.011$ & 3.087 & 0.99 & 0.99 & $0.260 \pm 0.022$ & 4.34 & 0.93 & $0.0008 \pm 0.0001$ & 15.81 & 0.94 \\
\hline
\end{tabular}

D-R isotherm relates the heterogeneity of energies close to the adsorbent surface. The values of $\mathrm{q}_{\mathrm{m}}(0.052 \pm 0.0008$ $\mathrm{mmol} / \mathrm{g})$ and $\mathrm{E}(15.81 \mathrm{KJ} / \mathrm{mol})$ are given in Table 1 . The estimated value of $E$ was $15.81 \mathrm{~kJ} / \mathrm{mol}$, which is the range expected for chemisorptions (8-16 kJ/mol) (Sawalha \& Videa, 2006). The values of $\mathrm{R}^{2}$ provide an indication of how well the experimental data fits with the isotherm models. From Table 1, it is evident that the Langmuir isotherm model exhibited a better fit to the equilibrium data for the MSD. Therefore, the uptake process can be interpreted as monolayer adsorption.

\subsection{Effect of Solution $p H$}

The $\mathrm{pH}$ of the solutions is one the most important variable governing metal adsorption. This is partly due to the competition between metal ions and $\mathrm{H}^{+}$ion for the adsorption onto the solid phase surface. The solution $\mathrm{pH}$ also influences the chemical speciation of the metal ions and the ionization of the active groups onto the adsorbent surfaces.

In order to evaluate the influence of this parameter on the adsorption, the experiments were carried out at different initial $\mathrm{pH}$ values by adding sufficient $\mathrm{HNO}_{3}$ solution. The $\mathrm{pH}$ range was chosen as $2-6$ in order to avoid the formation of lead hydroxides. The results are shown in Figure 7 in which percentages of extraction $(\% \mathrm{E})$ are plotted against the initial $\mathrm{pH}$ of the solution. An inspection of this figure shows that the uptake of lead cation from aqueous solution is slightly influenced by $\mathrm{pH}$. This is because ethers are comparatively stable non-reactive compounds. The ether linkage is quite stable towards bases, oxidizing agents, reducing agents and some acids like $\mathrm{HCl}$ and $\mathrm{HNO}_{3}$. Cleavage takes place under quite vigorous conditions: concentrated acids (usually $\mathrm{HI}$ or $\mathrm{HBr}$ ) and high temperatures.

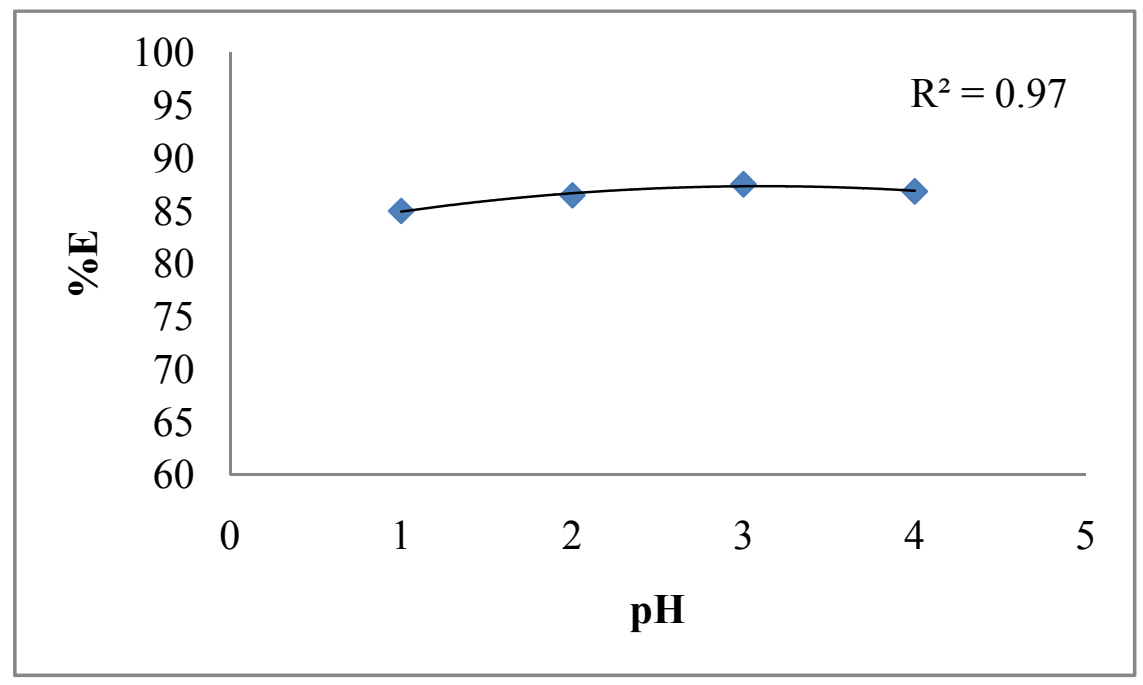

Figure 7. Effect of $\mathrm{pH}$ on the uptake of lead cation from aqueous solution at $25^{\circ} \mathrm{C}$ by MSD

\subsection{Effect of Temperature and Determination of Adsorption Thermodynamics}

The removal of lead cations by MSD as a function of temperature is illustrated in Figure 8. Insignificant changes in the extracting ability of MSD were observed by increasing the temperature. During the sorption process, the transfer of cation salt (dependant on counter-ion) from aqueous to solid phase as well as the affinity of the active sites of the material for that particular ion are to be considered. Therefore, the variation in extraction with temperature must be attributed to either or both processes. 


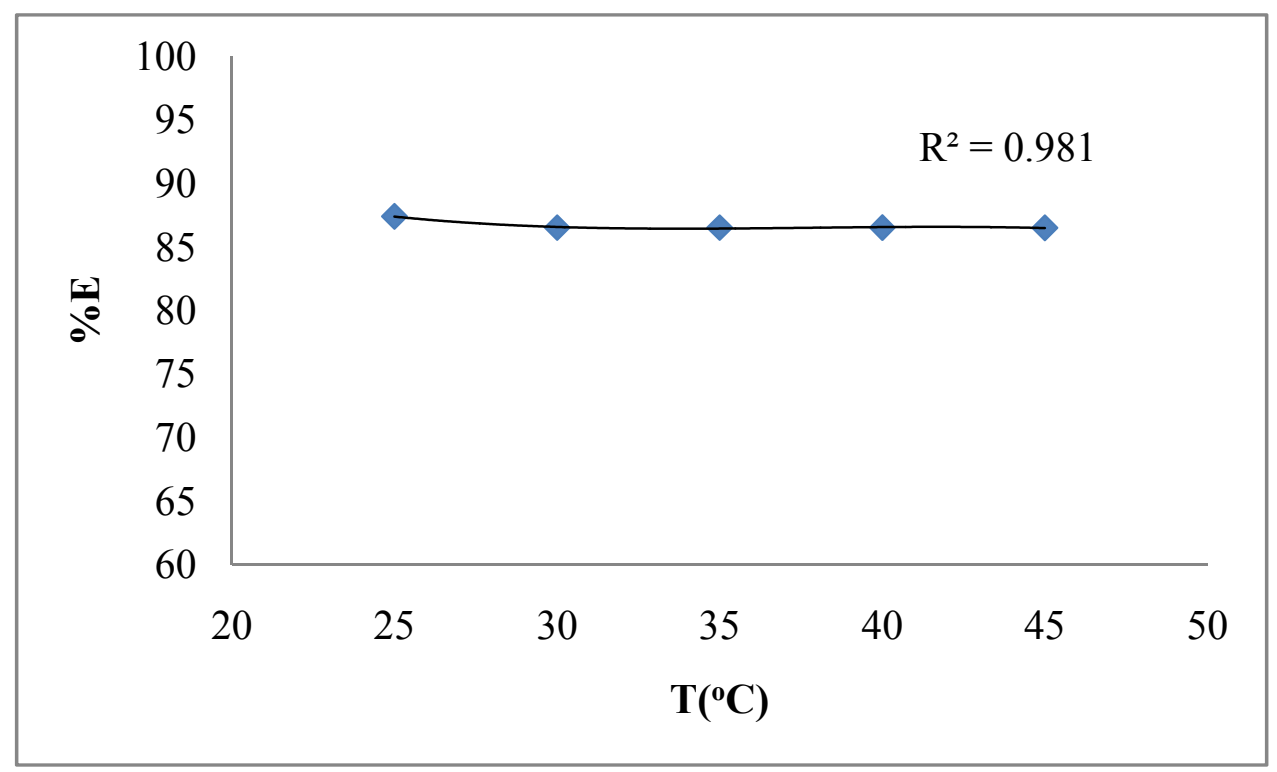

Figure 8. Effect of temperature on the uptake of lead cations from aqueous solution by the MSD

The adsorption equilibrium data obtained for different temperatures were used to calculate the important thermodynamic properties such as standard Gibbs free energy $\left(\Delta \mathrm{G}^{\circ}\right)$, standard enthalpy change $\left(\Delta \mathrm{H}^{\circ}\right)$ and standard entropy change $\left(\Delta \mathrm{S}^{\circ}\right)$ (Namasivayam \& Yamuna, 1995). The standard Gibbs free energy was evaluated by

$$
\Delta G=-R T \ln K_{c}
$$

The equilibrium constant $\mathrm{K}_{\mathrm{c}}$ was calculated using the relationship:

$$
K_{c}=\frac{\left[P b^{2+}\right]_{\text {extracted }}}{\left[P b^{2+}\right]_{\text {remained }}}
$$

Where, $\left[\mathrm{Pb}^{2+}\right]_{\text {extracted }}$ and $\left[\mathrm{Pb}^{2+}\right]_{\text {remained }}$ are the equilibrium concentration of $\mathrm{Pb}$ (II) on the adsorbent and solution respectively.

The standard enthalpy $\left(\Delta \mathrm{H}^{\circ}\right)$ and entropy $\left(\Delta \mathrm{S}^{\circ}\right)$ of adsorption were determined from the Van't Hoff equation,

$$
\ln K_{c}=\frac{\Delta S^{o}}{R}-\frac{\Delta H^{o}}{R T}
$$

Where, $\Delta \mathrm{H}^{\circ}$ and $\Delta \mathrm{S}^{\circ}$ were obtained from the slope and intercept of the Van't Hoff's plot of $\ln \mathrm{K}_{\mathrm{c}}$ versus $1 / \mathrm{T}$ as shown in Figure 9. 


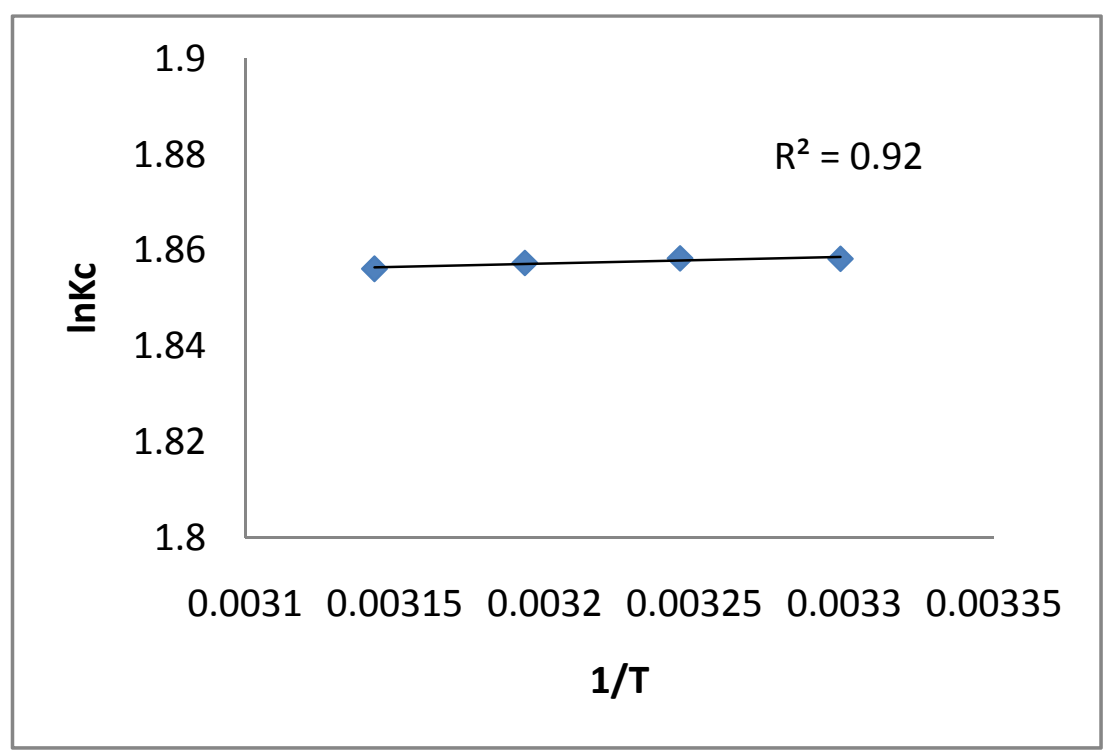

Figure 9. Van’t Hoff plot for MSD

The results of the thermodynamic calculations are shown in Table 2. It was found that the negative Gibbs free energy indicating the adsorption process is spontaneous in nature. The overall adsorption process seems to be exothermic $\Delta \mathrm{H}^{\circ}(-0.116 \pm 0.010 \mathrm{KJ} / \mathrm{mol})$. This result also supports the suggestion that the resulting $\mathrm{Pb}$-adsorbent complex is energetically stable. The positive $\Delta \mathrm{S}^{\circ}(0.020 \pm 0.002 \mathrm{KJ} / \mathrm{mol} \mathrm{K})$ suggests an increased randomness at the solid-liquid interface during the process of adsorption. During the removal of $\mathrm{Pb}$ (II) cations, the water molecules, which are displaced by the $\mathrm{Pb}$ (II) ions, gain more translational and rotational entropy than is lost by the cations, thus allowing for the increase of randomness in the system (Orhan \& Bugukgunor, 1993).

Table 2. Thermodynamic parameters for the removal of lead cations by the MSD

\begin{tabular}{cccc}
\hline $\mathrm{T}(\mathrm{K})$ & $\Delta \mathrm{G}^{\mathrm{o}}(\mathrm{KJ} / \mathrm{mol})$ & $\Delta \mathrm{H}^{\mathrm{o}}(\mathrm{KJ} / \mathrm{mol})$ & $\Delta \mathrm{S}^{\mathrm{o}}(\mathrm{KJ} / \mathrm{mol} . \mathrm{K})$ \\
\hline 298 & $-4.790 \pm 0.05$ & $-0.116 \pm 0.010$ & $0.020 \pm 0.002$ \\
303 & $-4.680 \pm 0.11$ & & \\
308 & $-4.761 \pm 0.12$ & & \\
313 & $-4.841 \pm 0.03$ & & \\
318 & $-4.909 \pm 0.11$ & & \\
\hline
\end{tabular}

\subsection{Kinetic Studies}

The influence of time on the removal of lead ions from aqueous solution was studied by determining the percentage of uptake of the $\mathrm{Pb}$ (II) cation salt at different time intervals (1-120 min). The temperature was kept at $25^{\circ} \mathrm{C}$ while other parameters such as the amount of the material, and the solution $\mathrm{pH}$ were kept optimum. The results are presented in Figure 10 in which percentages of extraction (\% E) are plotted against the contact time. The results show that the percentage of removal of $\mathrm{Pb}$ (II) ions increases with an increase in the contact time before equilibrium is reached. It is obvious that increase in contact time from 5 to 20 min enhanced significantly the percent removal of metal ions. This result revealed that adsorption of $\mathrm{Pb}(\mathrm{II})$ is fast and the equilibrium was achieved by $1 \mathrm{~h}$ of contact time. The nature of adsorbent and its available sorption sites affected the time needed to reach the equilibrium. The presence of oxygen atoms as donor sites significantly improved the binding capacity and the kinetics of the extraction process. 


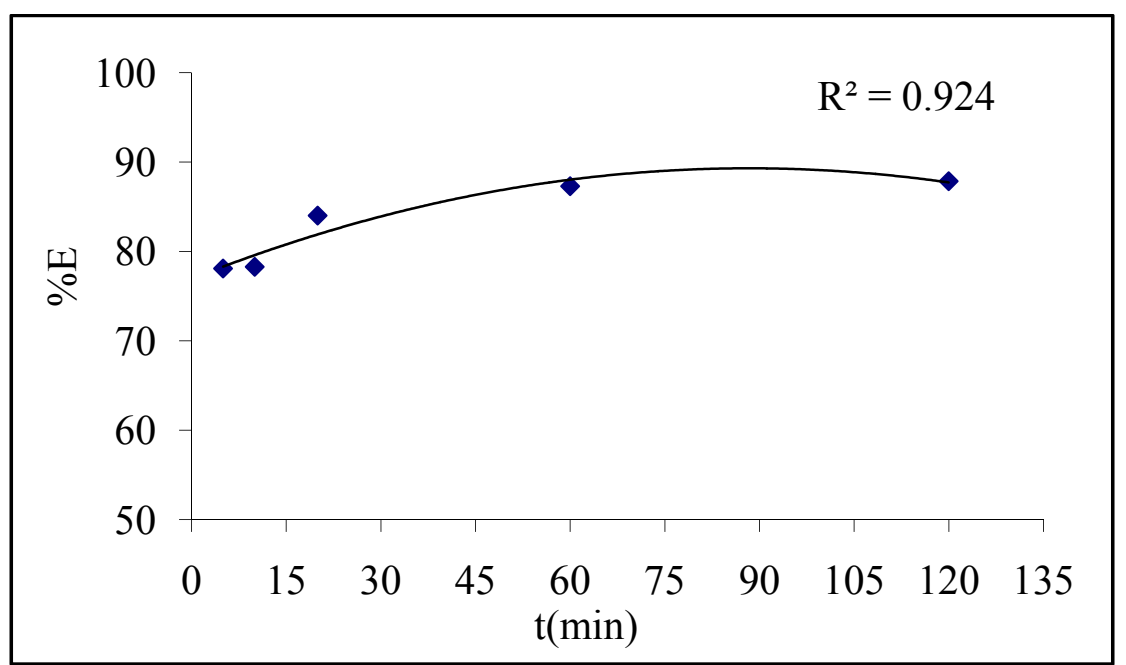

Figure 10. Optimum time for the uptake of $\mathrm{Pb}(\mathrm{II})$ cations from aqueous solution at $25^{\circ} \mathrm{C}$ by MSD

In order to examine the controlling mechanisms of adsorption processes two kinetic models, pseudo first order and pseudo second order, are used to test the experimental data.

\subsection{Pseudo First Order Model}

The adsorption data were fitted to the Lagergren's pseudo first order rate equation (Lagergren, 1898):

$$
\frac{d q_{t}}{d t}=K_{l}\left(q_{e}-q_{t}\right)
$$

On integration from $\mathrm{q}_{\mathrm{t}}=0$ at $\mathrm{t}=0$, gives:

$$
\ln \left(q_{e}-q_{t}\right)=\ln \left(q_{e}-K_{l} t\right)
$$

Where $q_{e}$ and $q_{\mathrm{t}}$ refer to the amount of $\mathrm{Pb}$ (II) ion adsorbed per unit weight of MSD ( $\mathrm{mg} \mathrm{g}^{-1}$ ) at equilibrium and at any time $\mathrm{t}(\mathrm{min})$. The value of $q_{e}$ and first order adsorption rate constant $\mathrm{K}_{1}\left(\mathrm{~min}^{-1}\right)$ can be obtained from the plot of $\ln \left(\mathrm{q}_{\mathrm{e}}-\mathrm{q}_{\mathrm{t}}\right) v s \mathrm{t}$.

\subsection{Pseudo Second Order Model}

It can be given as (Ho, \& McKay, 1982):

$$
\frac{d q_{t}}{d t}=K_{2}\left(q_{e}-q_{t}\right)^{2}
$$

Separating the variables and integrating; where $\mathrm{q}_{\mathrm{t}}=0$ at $\mathrm{t}=0$ and $\mathrm{q}_{\mathrm{t}}=\mathrm{q}_{\mathrm{t}}$ at $\mathrm{t}=\mathrm{t}$, gives:

$$
\frac{t}{q_{t}}=\left(\frac{1}{K_{2} q_{e}^{2}}\right)+\left(\frac{t}{q_{e}}\right)
$$

The product $K_{2} q_{e}^{2}$ is the initial sorption rate. A plot of $\mathrm{t} / \mathrm{q}_{\mathrm{t}}$ against $\mathrm{t}$ provides second order adsorption rate constants $\mathrm{K}_{2}$ and $\mathrm{q}_{\mathrm{e}}$ values from the slopes and intercepts.

The applicability of the models mentioned above was checked by attempting to obtain a linear fit of the experimental data by the appropriate equations. Kinetic constants along with their regression coefficient data for lead removal using MSD are given in Table 3.

Table 3. Kinetic constants for the removal of lead cations by MSD at $25^{\circ} \mathrm{C}$

\begin{tabular}{llllllll}
\hline \multicolumn{2}{l}{ Pseudo first order model } & & & \multicolumn{3}{l}{ Pseudo second order model } \\
\cline { 1 - 2 } \cline { 6 - 7 } $\mathrm{K}_{1}\left(\mathrm{~min}^{-1}\right)$ & $\mathrm{q}_{\mathrm{e}}\left(\mathrm{mg} \mathrm{g}^{-1}\right)$ & $\mathrm{R}^{2}$ & & $\mathrm{~K}_{2}\left(\mathrm{~g} \mathrm{mg}^{-1} \mathrm{~min}^{-1}\right)$ & $\mathrm{q}_{\mathrm{e}}\left(\mathrm{mg} \mathrm{g}^{-1}\right)$ & $\mathrm{R}^{2}$ \\
\hline $0.05 \pm 0.11$ & 0.012 & 0.97 & & $9.91 \pm 0.08$ & 0.11 & 0.99 \\
\hline
\end{tabular}


The experimental $\mathrm{q}_{\mathrm{e}}$ values were compared with $\mathrm{q}_{\mathrm{e}}$ values determined by the pseudo first order kinetic model (Figure 11) and the pseudo second order kinetic model (Figure 12).

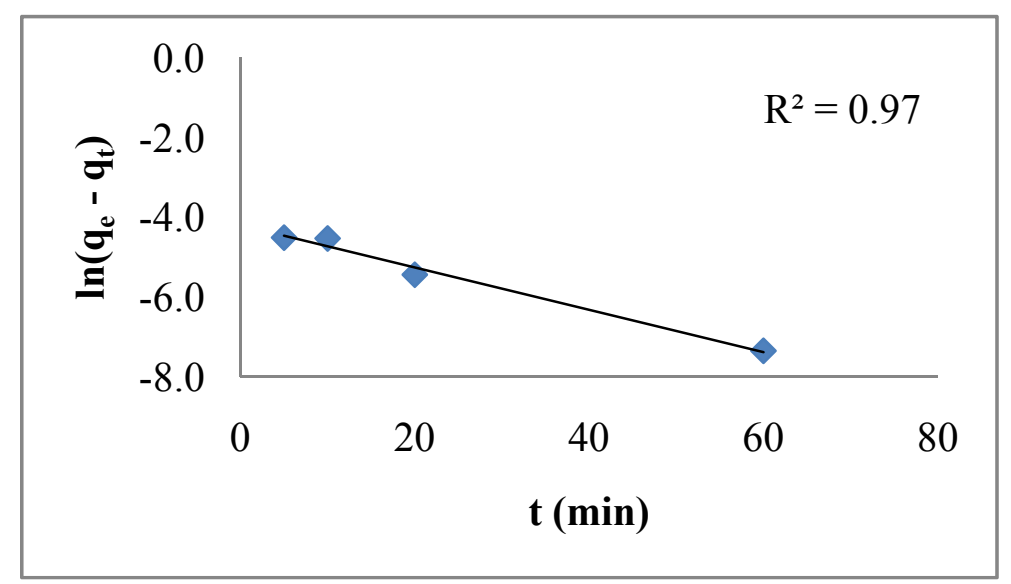

Figure 11. Pseudo first order kinetic plot for the sorption of lead cations by the MSD

For the first order rate expression, calculated qe value is higher than the experimental one. A good agreement of the experimental data with the second order kinetic model was observed which is presented in Figure 12. The correlation coefficients for the second order kinetic models $\left(\mathrm{R}^{2}=0.99\right)$ and the calculated $q_{\mathrm{e}}$ values agree very well with the experimental data which indicates chemisorptions mechanism. The pseudo second order model is based on the assumption that the rate-limiting step is a chemical sorption between the lead cation and the MSD.

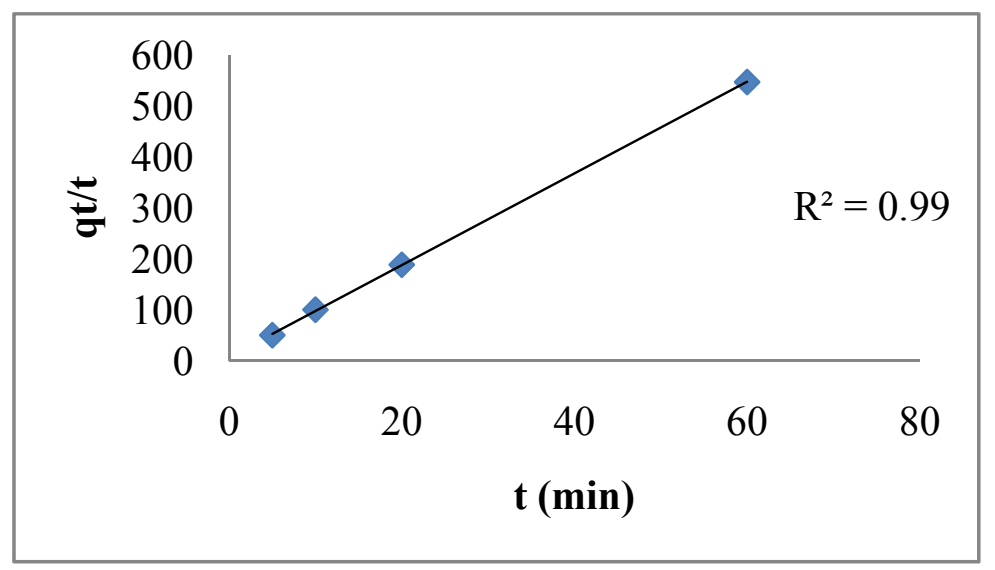

Figure 12. Pseudo second order kinetic plot for the sorption of lead cations by the MSD

Table 4. Comparison of MSD with some reported sorbents for lead cations

\begin{tabular}{ccc}
\hline Material & Capacity $(\mathrm{mg} / \mathrm{g})$ & Reference \\
\hline MSD & 78.10 & Current work \\
Undyed sawdust & 7.30 & Shukla and Sakhardanre, 1992 \\
Petiolar felt-sheath pf palm & 11.40 & Iqbal et al., 2002 \\
Granular activated carbon & 16.58 & Zacaria et al., 2002 \\
Peanut hulls & 30.04 & Zacaria et al., 2002 \\
rice husk ash & 91.74 & Naiya et al., 2009 \\
phosphorylated sawdust & 383.13 & Jeon et al., 2009
\end{tabular}




\section{Comparison with Alternative Materials}

In general, the direct comparison of modified saw dust with other adsorbents is complicated owing to the different applied experimental conditions. It was found that the uptake capacity of the MSD $(78.1 \mathrm{mg} / \mathrm{g})$ for lead ions is comparable with that of other adsorbents and in fact greater than certain materials (Table 4). The properties of an ion in a aqueous media are determined mainly by ion-solvent and ion-ion interactions (Jeong \& Park, 1999; Danil de Namor, Pugliese, Casal, Llerena, Aymonino, \& Velarde, 2000). The molar Gibbs energy of the ion transfer from one phase to another, $\Delta_{t} \mathrm{G}$, gives a comparison of the solvation of the ion in both media. Therefore, the uptake capacity of any material for a given ion changes extensively by changing the counter-ion. Therefore, the comparison must be done with adsorbents for removing of cations with the same counter ion.

Modified saw dust demonstrates fast lead uptake. It is of low cost, easily prepared, shows comparable capacity level and convenient method for the removal of lead ions from aqueous media.

\section{Conclusions}

This paper presents the outcome of a detailed study of thermodynamics and kinetics of the sorption process for removing $\mathrm{Pb}$ (II) ions from aqueous solution using modified saw dust. These results provide a good indication of the different operating conditions that would be required for the efficient removal of $\mathrm{Pb}(\mathrm{II})$ from aqueous solution. Increase in mass of adsorbent leads to increase in metal ion adsorption due to increase in number of active sites. The adsorption capacity of the MSD for $\mathrm{Pb}$ (II) was $78.1 \mathrm{mg} / \mathrm{g}$ and the adsorption rate $\left(\mathrm{k}_{2}\right)$ was $9.92 \mathrm{~g} / \mathrm{mg}$ min. The equilibrium adsorption behavior of lead ions by the MSD was found to obey the Langmuir adsorption isotherm. The mean free energy obtained from the D-R model indicated that, the removal of lead ions using MSD was a chemical adsorption process.

\section{Acknowledgement}

The authors gratefully acknowledge the financial and technical support of this work by CNRS.

\section{References}

Abdel-Halim, S. H., Shehta, A. M. A., \& El-Shahat, M. F. (2003). Removal of lead ions from industrial wastewater by different types of natural materials. Water Res., 37, 1678-1683. http://dx.doi.org/10.1016/S0043-1354(02)00554-7

Abraham, B. T., \& Anirudhan, T. S. (2001). Sorption recovery of metal ions from aqueous solution using humus-boehmite complex. Indian J. Chem. Technol., 8, 286-292.

Bhattacharya, A. K., Naiya, T. K., Mandal, S. N., \& Das, S. K. (2008). Adsorption, kinetics and equilibrium studies on removal of $\mathrm{Cr}(\mathrm{VI})$ from aqueous solution using different low cost adsorbents. Chem. Eng. J., 137 (5), 529-541.

Chakravarti, A. K., Chwodhury, S. B., Chakraborty, S., Chakraborty, T., \& Mukherjee, D. C. (1995). Liquid membrane multiple emulsion process of chromium (VI) separation from wastewaters. Colloids Surf. A: Physicochem. Eng. Aspects, 103, 59-71. http://dx.doi.org/10.1016/0927-7757(95)03201-N

Danil de Namor, A. F., \& Abbas, I. (2010). Diethyl sulfide modified silica and calix[4]pyrrole chelating resin: Synthesis and mercury(II) cation retention properties. Anal. Methods., 2(63), 63-71. http://dx.doi.org/10.1039/b9ay00135b

Dubinin, M. M., \& Radushkevich, L. V. (1947). Proceedings of the Academy of Sciences, Physical Chemistry Section. U.S.S.R., 55, 331-333.

Hirata, S., Honda, K., \& Kumamru, T. (1989). Trace metal enrichment by automated on-line column preconcentration for flow-injection atomic absorption spectrometry. Anal. Chim. Acta, 221, 65-76. http://dx.doi.org/10.1016/S0003-2670(00)81939-X

Inoue, K., Ohto, K., Yoshizuka, K., Yamaguchi, T., \& Tanaka, T. (1997). Sorption of lead(II) ion on complexane type of chemically modified chitosan. Bull. Chem. Soc. Jpn., 70, 2443-2447. http://dx.doi.org/10.1246/bcsj.70.2443

Kongsricharoern, N., \& Polprasert, C. (1996). Chromium removal by a bipolar electrochemical precipitation process. Water Sci. Technol., 34, 109-116. http://dx.doi.org/10.1016/S0273-1223(96)00793-7

Low, K. S., Lee, C. K., \& Liew, S. C. (2000). Sorption of cadmium and lead from aqueous solution by spent grain. Proc. Biochem., 36, 59-64. http://dx.doi.org/10.1016/S0032-9592(00)00177-1

Mandaoker, S. S., Dharmadhikari, D. M., \& Dara, S. S. (1994). Reterival of heavy metal ions from solution by 
ferritization. Environ. Pollut., 83, 277-282.

Namasivayam, C., \& Yamuna, R. T. (1995). Adsorption of chromium (VI) by a low cost adsorbent: biogas residual slurry. Chemosphere, 30(3), 561-578.

Orhan, Y., \& Büyükgüngor, H. (1993). The removal of heavy metals by using agricultural wastes. Water Sci. Technol., 28(2), 247-255.

Ortiz, I., Roman, M. F. S., Corvalan, S. M., \& Eliceche, A. M. (2003). Modeling and optimization of an emulsion pertraction process for removal and concentration of $\mathrm{Cr}(\mathrm{VI})$. Ind. Eng. Chem. Res., 42, 5891-5899. http://dx.doi.org/10.1021/ie030212f

Parab, H., Joshi, S., Shenoy, N., Lali, A., Sarma, U. S., \& Sudersanan, M. (2008). Esterified coir pith as an adsorbent for the removal of Co(II) from aqueous solution. Bioresource Technology, 99(6), 2083-2086. http://dx.doi.org/10.1016/j.biortech.2007.03.058

Park, K. H., Park, M. A., Jang, H., Kim, E. K., \& Kim, Y. H. (1999). Removal of heavy metals cadmium(II) and lead(II) ions in water by sargassum. Adsorption Sci. Technol., 12, 196-202.

Raji, C., Shubha, K. P., \& Anirudhan, T. S. (1997). Use of chemically modified saw dust in the removal of lead(II) ions from aqueous media. Indian J. Environ. Health, 39, 230-238.

Reed, B. E., Arunachalam, S., \& Tomes, B. (1994). Removal of lead and cadmium from aqueous solutions using granular activated carbon columns. Environ. Progr., 13, 60-64.

Sawalha, M. F., Videa, J. R. P., Gonzalez, J. R., \& Gardea-Torresdey, J. L. (2006). Biosorption of Cd(II), Cr(III), and $\mathrm{Cr}(\mathrm{VI})$ by saltbush. J. Colloidal and Interface Sci., 300, 100-104. http://dx.doi.org/10.1016/j.jcis.2006.03.029

Shubha, K. P., Raji, C., \& Anirudhan, T. S. (2001). Immobilization of heavy metals from aqueous solutions using polyacrylamide grafted hydrous tin(IV) oxide gel having carboxylate functional groups. Water Res., 35, 300-310. http://dx.doi.org/10.1016/S0043-1354(00)00234-7

Stuart, B. (1996). Modern Infrared Spectroscopy. Chister, UK: Wiley.

Trgo, M., Peric, J., \& Medvidovic, N. V. (2006). A comparative study in ion exchange kinetics in zinc/lead-modified zeolite-clinoptilite systems. J. Hazard. Mater., 136, 938-945. http://dx.doi.org/10.1016/j.jhazmat.2006.01.032 